\title{
Relationship Obesity in Pregnancy with Preeclampsia in Sidoarjo General Hospital
}

\author{
$1^{\text {st }}$ Evi Rinata \\ Midwifery Program, Faculty of Health \\ Science, Universitas Muhammadiyah \\ Sidoarjo \\ Jl Majapahit 666-B Sidoarjo 61215 \\ Indonesia \\ evi.rinata@umsida.ac.id
}

\author{
$2^{\text {nd }}$ Zahro Rosyidah Mustikaningrum \\ Midwifery Program, Faculty of Health \\ Science, Universitas Muhammadiyah \\ Sidoarjo \\ J1 Majapahit 666-B Sidoarjo 61215 \\ Indonesia
}

\begin{abstract}
Obesity is one of the factors causing preeclampsia. Based on observational survey data at the Afifa Primary Clinic and Maternity Clinic in Prambon conducted during the month of August 2017, out of 10 pregnant women 1 had severe pre-eclampsia, 1 person had mild preeclampsia, and 1 person with gestational hypertension. The data shows the high incidence of preeclampsia in the Afifa Primary Clinic and Maternity Clinic in Prambon. The purpose of this study was to determine the relationship of obesity in pregnant women with the incidence of preeclampsia. The research design used was a retrospective analytic survey with chi-square statistical tests using software to determine the relationship. The study population was pregnant women who made a pregnancy visit in the Sidoarjo General Hospital during January-June 2018 totaling 258 mothers. And the sample taken was 157 mothers and was taken by systematic random sampling. The results showed that preeclampsia was more experienced by obese mothers $(37.6 \%)$ when compared to non-obese mothers $(\mathbf{1 1 . 1 \%})$. While the condition of not preeclampsia is more experienced by mothers who are not obese $(88.9 \%)$ when compared with mothers who are obese $(62.4 \%)$. The Chi square test results obtained $p$ value $<0.001$ which means $p<\alpha$ so that $\mathrm{HO}$ is rejected. It can be concluded that there is a relationship between obesity and the incidence of preeclampsia in pregnancy. So it is recommended to health workers to improve intensive care for obese mothers to reduce the incidence of preeclampsia.
\end{abstract}

\section{Keywords-Obesity, Pregnancy, Preeclampsia}

\section{INTRODUCTION}

Preeclampsia is a complication in pregnancy and childbirth that begins to experience during pregnancy reaches the age of 20 weeks with a marked increase in systolic blood pressure $\geq 30 \mathrm{mmHg}$ and diastole $\geq 15$ $\mathrm{mmHg}$, or with blood pressure $\geq 140 / 90 \mathrm{mmHg}$ accompanied by the discovery of proteinuria in pregnant women [1]. Preeclampsia is the 3rd largest cause of maternal death after bleeding and infection [2]. The incidence of preeclampsia and eclampsia in Indonesia has increased. The facts found, $25 \%$ of maternal deaths in Indonesia in 2013 were caused by Hypertension in Pregnancy. In 2010, data showed that $21.5 \%$ of cases of maternal deaths were caused by hypertention in pregnancy. In 2011, it increased to $24.7 \%$. In 2012, it increased again to $26.9 \%$, in 2013 it increased to $27.1 \%$. Eclampsia causes $31 \%$ of cases of maternal death or as many as 162 people die within 1 year [3]. In Sidoarjo, patient data received by Sidoarjo Regional Hospital about cases of preeclampsia throughout 2017 are as many as 512 patients and this case is the main cause of maternal death in Sidoarjo.

Obesity is a condition with a body mass index or BMI $\geq 30$. Worldwide, obesity cases have tripled since 1975 . In 2016, more than 1.9 billion adults were overweight, aged 18 years or older overweight, and more than 650 million are obese. The most likely impact of this case is the increased risk of cardiovascular disease (where this case is the main cause of death in 2012), diabetes, musculoskeletal diseases, and cancer [4]. Nonpregnant women who are obese have a risk of metabolic derangements including a disruption in cholesterol metabolism which triggers endothelial dysfunction [13]. Endothelial dysfunction that occurs during pregnancy can increase the risk of placental ischemia, vascular inflammation, vascular dysfunction, and trigger hypertension in pregnancy will cause preeclampsia.

Based on data of pregnant women in San Bernardino County USA who experienced preeclampsia or eclampsia and were obese in 2007 were $33.90 \%$. While in 2008 the number of pregnant women who experienced preeclampsia or eclampsia and obesity increased to $35.13 \%$. The increase in the number of people suffering from preeclampsia and eclampsia is expected to be higher along with the increase in cases of obesity throughout the world [16]. Observation survey data at the Afifa Prambon Primary Clinic and Maternity Clinic conducted during August 2017, out of 10 pregnant women 1 had severe preeclampsia, 1 person had mild preeclampsia, and 1 more with gestational hypertension. From the results of these observations, it is necessary to do research on the factors associated with the occurrence of preeclampsia. 


\section{METHOD}

This study is a retrospective study with an analytic survey design. The study was designed by collecting prepregnancy body weight and maternal height data by tracking the medical records of patients undergoing antenatal care at the Sidoarjo General Hospital. The population is all pregnant women who have a UK> 20 weeks recorded in the medical record or register of the Sidoarjo Regional General Hospital from January-June 2018 as many as 258 mothers and taken as many as 157 mothers.

The population criteria in this study were data on height and weight before pregnancy, not hypertension before pregnancy, single pregnancy, normal BUN level, normal blood sugar, and not having placental vascular disorders. The sampling technique is carried out by probability sampling technique, with a systematic random sampling technique. The research instrument used is a table of research data recapitulation.

The data collected is presented in the form of frequency tabulation and cross tabulation. Then analyzed using computer software through chi-square test to see the relationship between obesity and the incidence of preeclampsia in pregnancy that can be tolerated $\alpha=0.05$.

\section{RESULT}

The results of the study concists of age, gravida status, history of large baby, history of twin pregnancy, history of polyhydramnios, history of hypertension, and history of diabetes, the incidence of preeclampsia and BMI status. Furthermore, the data will be presented in the form of a frequency distribution table and cross tabulation.

TABLE I. MATERNAL CHARACTERISTIC \& OBSTETRIC HISTORY OF PREGNANT WOMEN UNDERGOING ANTENATAL CARE IN SIDOARJO GENERAL HOSPITAL DURING JANUARYJUNE 2018

\begin{tabular}{|c|c|c|}
\hline $\begin{array}{c}\text { Maternal Characteristic \& } \\
\text { Obstetric History }\end{array}$ & N & Percent \% \\
\hline Maternal Age & & \\
\hline Age at risk (<20 and >35) & 37 & 23,6 \\
\hline Recommended age (20-35) & 120 & 76,4 \\
\hline Total (n=157) & & \\
\hline Gravida Status & 35 & 22,3 \\
\hline Primigravida & 122 & 77,7 \\
\hline Multigravida & & \\
\hline Total (n=157) & & \\
\hline Large Baby & 2 & 1,2 \\
\hline Experienced & 155 & 98,8 \\
\hline Not Experienced & & \\
\hline Total (n=157) & 0 & 0 \\
\hline Twin Pregnancy & 157 & 100 \\
\hline Experienced & & \\
\hline Not Experienced & & \\
\hline Total (n=157) & 1 & 0,6 \\
\hline Polyhidramnion & 156 & 99,4 \\
\hline Experienced & & \\
\hline Not Experienced & & \\
\hline Total (n=157) & 24 & 15,3 \\
\hline Hypertension & 133 & 84,7 \\
\hline Experienced & & \\
\hline Not Experienced & 98 & $37,6 \%$ \\
\hline Total (n=157) & & $62,4 \%$ \\
\hline Gestational Age & & \\
\hline $2^{\text {nd }}$ Trimester & & \\
\hline $3^{\text {rd }}$ Trimester & & \\
\hline & & \\
\hline & & \\
\hline & & \\
\hline & & \\
\hline & & \\
\hline & & \\
\hline & & \\
\hline
\end{tabular}

\begin{tabular}{|l|c|c|}
\hline Total $(\mathrm{n}=157)$ & & \\
\hline Diabetes & & \\
\hline Experienced & 15 & 9,5 \\
\hline Not Experienced & 142 & 90,5 \\
\hline Total $(\mathrm{n}=157)$ & & \\
\hline
\end{tabular}

TABLE II. OBESITY STATUS AND DISTRIBUTION OF OBESITY LEVEL OF PREGNANT WOMEN UNDERGOING ANTENATAL CARE IN SIDOARJO GENERAL HOSPITAL DURING JANUARYJUNE 2018

\begin{tabular}{|c|c|c|}
\hline $\begin{array}{c}\text { Obesity Status \& Distribution of } \\
\text { Obesity Level }\end{array}$ & $\mathrm{N}$ & Percent \% \\
\hline Obesity Status & & \\
\hline Obese & 85 & 25,5 \\
\hline Not Obese & 72 & 74,5 \\
\hline Total (n=157) & & \\
\hline Obesity Level & & \\
\hline Level I & 48 & 56,5 \\
\hline Level II & 37 & 43,5 \\
\hline Total (n=85) & & \\
\hline
\end{tabular}

TABLE III. DISTRIBUTION OF THE INCIDENCE OF PREECLAMPSIA IN PREGNANT WOMEN UNDERGOING ANTENATAL CARE IN SIDOARJO GENERAL HOSPITAL DURING JANUARY-JUNE 2018

\begin{tabular}{|c|c|c|}
\hline $\begin{array}{c}\text { Obesity Status \& Distribution of } \\
\text { Obesity Level }\end{array}$ & $\mathrm{N}$ & Percent \% \\
\hline Status of Preeclampsia & & \\
\hline Preeclampsia & 40 & 25,5 \\
\hline Not Preeclampsia & 117 & 74,5 \\
\hline Total (n=157) & & \\
\hline Distribution of Preeclampsia & & \\
\hline Superimposed Preeclampsia & 13 & 32,5 \\
\hline Mild Preeclampsia & 13 & 32,5 \\
\hline Severe Preeclampsia & 14 & 35 \\
\hline HELLP Syndrome & 0 & 0 \\
\hline Eclampsia & 0 & 0 \\
\hline Total (n=40) & & \\
\hline
\end{tabular}

TABEL IV. CROSS TABULATION OF OBESITY AND PREECLAMPSIA AMONG PREGNANT WOMEN IN SIDOARJO GENERAL HOSPITAL DURING JANUARY-JUNE 2018

\begin{tabular}{|c|c|c|c|}
\hline \multirow{2}{*}{ Obese (BMI) } & \multicolumn{2}{|c|}{ Status of Preeclampsia } & \multirow{2}{*}{ N $(\%)$} \\
\cline { 2 - 3 } & $\begin{array}{c}\text { Preeclampsia } \\
(\%)\end{array}$ & $\begin{array}{c}\text { Not Preeclampsia } \\
(\%)\end{array}$ & \\
\hline Obese $(\geq 25)$ & $32(37,6 \%)$ & $53(62,4 \%)$ & $85(100 \%)$ \\
\hline Not Obese $(<25)$ & $8(11,1 \%)$ & $64(88,9 \%)$ & $72(100 \%)$ \\
\hline Total & $40(25,5 \%)$ & $117(74,5 \%)$ & $157(100 \%)$ \\
\hline
\end{tabular}

Chi Square test $\mathrm{p}<0.001$

Tabel 4. showed that preeclampsia was more experienced by obese mothers $(37.6 \%)$ than non-obese mothers $(11.1 \%)$. While the condition of not preeclampsia is more experienced by mothers who are not obese $(88.9 \%)$ than obese mothers $(62.4 \%)$. The chi-square test results obtained $\mathrm{p}$-value $<0.001$ which means that $\mathrm{p}<\alpha$ then $\mathrm{H} 0$ was rejected so it was concluded that there was a relationship between obesity and the incidence of preeclampsia in pregnancy.

\section{DISCUSSION}

A. Overview of Obesity in Pregnant Women in Sidoarjo General Hospital

In table 2 the results of the majority of mothers (54.14\%) who examined themselves at the Sidoarjo General Hospital were obese. According to the theory [5], 
the criteria for obesity in the Asia Pacific population are divided into 2. The obesity group level I (BMI 25.0-29.9) and the obesity group level II (IMT $\geq 30.0$ ). Based on the theory [5] regarding the classification of obesity, we found the distribution of obesity level in pregnant women who checked themselves in Sidoarjo General Hospital according to table 10 as follows: of 85 pregnant women who were obese at the level I, 48 mothers $(56.5 \%)$. While the number of pregnant women who are obese level II is as many as 37 mothers (43.5\%) of the total pregnant women who are obese. The condition of obesity does not necessarily occur. This is usually triggered by several factors including heredity, environment, drugs, psychology, development, and physical activity. Chronic obesity can cause hormonal imbalance in sexuality, increasing free fatty acids, and mechanical stress [6].

Obesity conditions allow a pregnant woman to experience serious complications during pregnancy. Especially if obesity lasts for a long time. Mothers can experience gestational diabetes, chronic hypertension or hypertension in pregnancy, disorders in the kidneys, and also heart disease [7].

Ways to maintain the condition of the weight of pregnant women include [8]: (1) determine the ideal body weight for pregnant women (according to the recommended BMI), (2) eat regularly (on time, exact dose, and proper nutrition), (3) regular physical activity, (3) weighing regularly (at least once a week), (4) changing habits to be healthier (such as consuming more water, multiplying fruit and vegetable consumption, pregnant gymnastics, etc).

\section{B. Overview of Preeclampsia in Pregnancy in Sidoarjo \\ General Hospital}

Nearly half of the pregnant women who went to the Sidoarjo General Hospital experienced preeclampsia $(25.5 \%)$ as shown in table 3. Based on geographical analysis and health facilities, Sidoarjo General Hospital is one of the referral hospitals where almost all patients who come for pregnancy visits is a patient with a high-risk pregnancy. In Table 12, of the 40 people who experienced preeclampsia and examined themselves in the Sidoarjo General Hospital throughout January-June 2018 the distribution was as follows: 13 mothers (32.5\%) experienced superimposed preeclampsia, 13 mothers $(32.5 \%)$ had mild preeclampsia, and there were 14 mothers $(35 \%)$ experiencing severe preeclampsia.

Preeclampsia or the stage before the occurrence of pregnancy poisoning is the incidence of hypertension in pregnancy accompanied by the presence of proteinuria and edema after 20 weeks' gestation or immediately after labor occurs [9]. While the factors that influence the occurrence of preeclampsia [1] include: preeclampsia and eclampsia is a complication whose exact cause is still unknown. However, the condition is thought to be influenced by several factors, including: primigravida, extreme age, hydatidiform mole, hereditary or hereditary factors, kidney diseases, pre-pregnancy hypertension (Essential Hypertension), multiple pregnancies, placental vascular disorders, diabetes mellitus, immunology, social factors, poor nutrition, smoking, and alcohol use.
As an example of primigravida factors that can cause preeclampsia. Primigravida is prone to the incidence of preeclampsia because women are first exposed to the chorion virus. This condition causes the mother's body to experience immunological mechanisms and the formation of blocking antibodies carried out by HLA-G (human leucocyte antigen $G$ ) against placental antigens that have not been formed completely so that the trophoblast implantation process to the decidual tissue of the mother is impaired. Primigravida is also susceptible to stress, which triggers the formation of the cortisol hormone where cortisol can increase sympathetic response so that cardiac output and blood pressure increase [10].

C. Relationship between Obesity in Pregnant Women and Preeclampsia in Sidoarjo General Hospital

The results showed that there was a relationship between obesity in pregnant women and the incidence of preeclampsia. The research data shown in table 4 shows that preeclampsia was more experienced by obese mothers $(37.6 \%)$ when compared to non-obese mothers $(11.1 \%)$. Whereas the condition of not preeclampsia is more experienced by mothers who are not obese $(88.9 \%)$ when compared to obese mothers $(62.4 \%)$. In accordance with the research conducted at RSUP Prof. dr. R. D. Kandou Manado which shows an association between obesity and the incidence of preeclampsia [11].

In accordance with the theory that obesity that occurs before pregnancy becomes a risk factor that can trigger several complications in pregnancy. If this condition is not maintained, the possibility of the mother to experience things related to disorders in the blood vessel system gets bigger. Such as the possibility of experiencing hypertension, gestational diabetes, and many other things [7].

This is according to the journal Epidemiology of preeclampsia: the impact of obesity, the obesity epidemic that is with $\mathrm{BMI} \geq 25 \mathrm{~kg} / \mathrm{m} 2$ that occurs throughout the world causes an increase in mortality and morbidity. Obesity increases the risk of CVD (Cardio Vascular Disease) [12]. In pregnant women who are obese, the risk of hypertension and preeclampsia tends to increase.

The potential for hypertension in pregnancy for pregnant women who are obese is caused by an increase in BMI causing inflammation in the placenta. Obese pregnant women will experience increased pressure on the formation of placental inflammatory cytokines and circulating IL-6 at the end of pregnancy. This condition increases the degree of muscularity in the placental muscle wall of pregnant women with obesity compared to pregnant women without obesity. The impact that occurs is that the blood vessels in the placenta experience constriction and the endothelial wall in them incline to be more rigid [13]. Blood flow will tend to be faster so that there is an increase in blood pressure in the mother [14].

The endothelial wall becomes more rigid due to a decrease in endothelial function due to obesity [13]. In fact, the endothelial function itself is mainly vascular endothelial cells, which regulate blood vessel homeostasis, maintain vasodilation and vasoconstrictions, inhibit and increase smooth muscle migration and 
proliferation, fibrinolysis and thrombogenesis and prevention and stimulation of platelet adhesion and aggregation, if the endothelial function has decreased as a whole will decrease. Unmanaged conditions will be causing permanent distraction of endothelial function [7]. In certain conditions, if it is not treated immediately it will cause the work of the kidneys to be disrupted so that the potential for preeclampsia is greater than for women whose BMI is normal, which is $<25 \mathrm{~kg} / \mathrm{m} 2$ [15] [14].

It is very important for women to maintain the pattern of nutrient intake during pregnancy so that obesity does not occur. Because the risk of greater complications occurs in women who experience chronic obesity. And less likely in pregnant women who are obese as a result of pregnancy [8]. The results of the study at the Sidoarjo General Hospital show that obese mothers before pregnancy experience preeclampsia during pregnancy and mothers who are not obese do not experience preeclampsia.

\section{CONCLUSION}

Based on the results of the study obtained conclusions as follows: Most mothers are obese, most mothers do not experience preeclampsia and there is a relationship between obesity and the incidence of preeclampsia during pregnancy where obese mothers before pregnancy experience preeclampsia and non-obese mothers before pregnancy do not experience preeclampsia. The relationship shows the need to increase intensive services in obese pregnant women so as not to develop preeclampsia.

\section{ACKNOWLEDGMENTS}

The authors acknowledged to Midwifery Program, Faculty of Health Sciences, Universitas Muhammadiyah Sidoarjo, and all staff of Sidoarjo General Hospital for helping this study. Also thanks to all the mothers who participated in this research.

\section{REFERENCES}

[1] Angsar, M. D. 2013. Hipertensi Dalam Kehamilan. In Ilmu Kebidanan Sarwono Prawirohardjo. Jakarta: PT. Bina Pustaka Sarwono Prawirohardjo.

[2] WHO. 2016. Media Centre: Maternal Mortality. November, 2016. http://www.who.int/mediacentre/factsheets/fs348/en/

[3] Profil Kesehatan Indonesia Tahun 2015. 2016. Kementrian Kesehatan Republik Indonesia. Open access: http://www.kemenkes.go.id

[4] WHO. 2017. Media Centre: Obesity and Overweight. Oktober, 2017. http://www.who.int/mediacentre/factsheets/fs311/en/

[5] Soegondo, S. 2006. Buku Ajar Ilmu Penyakit Dalam: Obesitas 4th ed. Jakarta: FK Universitas Indonesia.

[6] Visscher, T.LS., Seidell, J.C. 2015.The Public Health Impact of Obesity. Annu. Rev. Public Health 2001. 22:355-75. www.annualreviews.org

[7] Hastuti, P. 2018. Genetika Obesitas. Yogyakarta: Gadjah Mada University Press.

[8] Irianto, K. 2014. Gizi Seimbang dalam Kesehatan Reproduksi (Balanced Nutrition in Reproductive Health). Bandung: Alfabeta.
[9] Manuaba, I. G. A. 2009. Gawat Darurat Obstetri Ginekologi \& Obstetri Ginekologi Sosial untuk Pendidikan Bidan. Jakarta: EGC.

[10] Denantika, O., Serudji, J., Revilla G. 2015. Hubungan Status Gravida dan Usia Ibu terhadap Kejadian Preeklampsia di RSUP Dr. M. Djamil Padang Tahun 2012-2013. Universitas Andalas. Jurnal Kesehatan Andalas 2015;4(1). http://jurnal.fk.unand.ac.id

[11] Dumais, C.E.G., Lengkong, R.A., Mewengkang, M.E. Hubungan Obesitas pada Kehamilan dengan Preeklampsia. Jurnal e-Clinic (e-Cl), Volume 4, Nomor 1, Januari-Juni 2016.

[12] Jayebalan, A. October 2013. Epidemiology of preeclampsia: Impact of Obesity. NIH Public Access Author Manuscript. doi: 10.1111/nure. 12055

[13] Spradley, F. T., Palel, A.C., Granger, J.P. 2015. Immune Mechanism Linking Obesity and Preeclampsia. Biomolcules $2015, \quad 5, \quad 3142-3176$. ISSN 2118-273X. www.mdpi.com/journal/biomolecules/

[14] Persson, M., et al. 2016, April 15. Maternal overweight and obesity and risk of preeclampsia in women with type 1 diabetes or type 2 diabetes. Diabetologis (2016) 59:2009-2105. DOI: 10.1007/s00125-016-4035-z. open access at Springerlink.com

[15] Itoh, H., Kanayama N. 2014. Obesity and Risk of Preeclampsia. Med J Abstet Gynecol 2(2): 1024.

[16] Lewis F, Modeste N, Singh P, Batech M, Tonstad S, Mataya R. 2014. Excess Maternal Body Weight and Preeclampsia/Eclampsia Risk among Women in San Benardino County, 2007-2008. September 26, 2014. Journal of Food and Nutrition $2014 \quad$ Vol 1:104 open access http://www.jscholaronline.org/ 